\title{
Penerapan Model Problem Based Learning (PBL) untuk Meningkatkan Proses dan Hasil Belajar Muatan PPKn pada Tema 8 Subtema 1
}

\author{
Inge Deautya Anindya Ifnasari ${ }^{*}$, Nyoto Harjono², Gamaliel Septian Airlanda ${ }^{3}$
}

1 Program Studi pendidikan Guru Sekolah Dasar - FKIP Universitas Kristen Satya Wacana

2 Program Studi pendidikan Guru Sekolah Dasar - FKIP Universitas Kristen Satya Wacana

${ }_{3}^{3}$ Program Studi pendidikan Guru Sekolah Dasar - FKIP Universitas Kristen Satya Wacana

\begin{abstract}
Abstrak
Penelitian ini memiliki tujuan untuk meningkatkan proses dan hasil belajar muatan PPKn siswa kelas 4 SD Ngipik pada tema 8 subtema 1 melalui model pembelajaran Problem Based Learning (PBL). Penelitian ini dilaksanakan dalam dua siklus dan dengan tiga kali pertemuan setiap siklusnya. Subjek pada penelitian ini adalah siswa kelas 4 SDN Ngipik. Teknik dalam pengumpulan data yang digunakan dalam penelitian tindakan kelas ini adalah tes, observasi, dan dokumentasi. Proses pembelajaran pada kondisi awal tindakan guru sebesar 70,53\% dan untuk tindakan siswa pada kondisi awal sebesar 71,73\%. Lalu di lanjutkan dengan tindakan siklus I pada tindakan guru pertemuan pertama mendapatkan $75,73 \%$ dan untuk siswa pada siklus I pertemuan pertama mendapatkan $78,51 \%$. Untuk siklus I pertemuan kedua tindakan guru mengalami kenaikan yaitu $78,59 \%$ dan untuk tindakan siswa juga mengalami kenaikan menjadi $82,86 \%$. Untuk siklus II pertemuan pertama tindakan guru juga mengalami kenaikan sebesar $90,47 \%$ dan tindakan siswa pada siklus II pertemuan kedua menjadi 90,48, pertemuan yang terakhir pada siklus II pertemuan kedua tindakan guru meningkat menjadi $100 \%$ dan tindakan siswa juga meningkat menjadi $100 \%$. Hasil penelitian yang sudah dilakukan juga menunjukkan adanya peningkatan perolehan proses hasil belajar. Pada saat kondisi awal sebesar 23,53\% siswa yang mencapai ketuntasan. Pada siklus I terjadi peningkatan menjadi 58,82\% yang sudah mencapai ketuntasan. Sedangkan untuk siklus II terjadi peningkatan menjadi $100 \%$ yang sama untuk ketuntasan. Dalam penelitian ini peneliti penerapan model pembelajaran PBL membuat siswa menjadi lebih aktif dan terjadinya interaksi antara siswa dengan siswa maupun siswa dengan guru sehingga dalam hal ini siswa mampu menyelesaikan permasalahan dan dapat meningkatkan proses dan hasil belajar muatan PPKn
\end{abstract}

\author{
Keywords: \\ Model PBL, Proses, \\ Hasil Belajar, PPKn
}

\section{PENDAHULUAN}

Dalam tujuan pendidikan nasional yang tertuang dalam UU Nomor 20 Tahun 2003 dinyatakan bahwa: "Pendidikan nasional berfungsi mengembangkan kemampuan dan membentuk watak serta peradaban bangsa yang bermartabat, bertujuan untuk berkembangnya potensi peserta didik agar menjadi manusia yang beriman dan bertaqwa kepada Tuhan Yang Maha Esa, berakhlak mulia, sehat, berilmu, kreatif, mandiri,dan menjadi warga negara yang demokratis serta bertanggung jawab". Berpijak pada tujuan pendidikan tersebut, pemerintah telah melakukan berbagai upaya untuk meningkatkan kualitas pendidikan seperti memberikan penghargaan terhadap guru, meningkatkan profesionalisme guru, menyediakan sarana dan prasarana serta menyusun dan menyempurnakan kurikulum (Widyasari, 2016).

Kurikulum yang ada di Indonesia dan baru saja disahkan oleh pemerintah adalah kurikulum 2013 Penerapan kurikulum 2013 ini secara serentak sudah diterapkan dari sekolah dasar hingga perguruan tinggi, berdasarkan Permendikbud Tahun 2013 kurikulum 2013 adalah suatu proses pembelajaran yang memberikan kesempatan bagi para siswa untuk dapat mengembangkan segala potensi yang dimiliki oleh siswa agar kemampuan yang dimiliki siswa dapat meningkat berdasarkan aspek sikap, pengetahuan, dan

\footnotetext{
* Corresponding author.

E-mail Addresses: - Ingedea15@gmail.com_(Inge Deautya Anindya Ifnasari), har.john59@gmail.com (Nyoto Harjono), 
keterampilan yang dilimiki siswa. Pada struktur kurikulum 2013, Kompetensi Inti merupakan tingkat kemampuan untuk mencapai Standar Kompetensi Lulusan yang harus dimiliki seorang peserta didik pada setiap tingkat kelas atau program yang menjadi landasan pengembangan kompetensi dasar (Widyaningrum, 2016).

Kemampuan ini diperlukan oleh siswa untuk siswa lebih giat dan lebih aktif dalam menerima pembelajaran yang diberikan. Tetapi dalam kenyataannya proses pembelajaran kurikulum 2013 belum berjalan sesuai dengan yang diharapkan. Kualitas pendidikan juga perlu ditingkatkan mengingat terjadinya persaingan global yang sesuai dengan perkembangan zaman. Untuk meningkatkan kualitas pendidikan perlu adanya peran para pendidik atau seorang guru dalam merancang pembelajaran yang bermakna dan dirancang melalui suatu kurikulum pendidikan. Seorang guru memiliki peranan yang sangat penting dalam implementasi suatu proses pembelajaran (Dewi, . Adapun secara hakiki pendidikan dilakukan sejak lahir sampai dewasa, keberhasilan pendidikan ini tidak terlepas dari proses belajar mengajar yang didalamnya terdapat beberapa kompnen yang saling berkaitan antara guru, siswa, materi, bahan dan alat, dan metode penyampainnya. (rahmasari, 2016).

Berdasarkan hasil observasi di SD Negeri Ngipik Kecamatan Pringsurat Kabupaten Temanggung kelas 4 pada tanggal 26 januari 2018 pukul 09.00 WIB , diketahui bahwa nilai muatan PPKn tema 6 masih kurang maksimal, hal ini terlihat dari 34 siswa yang mengikuti pembelajaran PPkn masih kurang dari nilai KKM yang ditentukan yaitu 7,00. Dari nilai KKM yang ditentukan tersebut terdapat 8 siswa yang tuntas dan ada 26 siswa yang belum tuntas. Kurang maksimalnya hasil belajar ini dikarenakan siswa kurang aktif di dalam kelas, adapun siswa juga kurang memahami setiap kata-kata yang ada dalam buku sehingga siswa sulit untuk memahami pembelajaran yang diberikan. Siswa kelas 4 terlihat kurang antusias dalam berinteraksi dengan guru, misalnya saja siswa takut bertanya dengan guru atau menjawab pertanyaan yang diberikan oleh guru dikarenakan siswa belum begitu memahami materi yang diberikan oleh guru dan ketika siswa akan menjawab pertanyaan dari guru atau bertanya sesuatu pertanyaan siswa takut salah menjawab dan salah bertanya. Disisi lain ketika guru menjelaskan di depan kelas siswa biasanya tidak langsung memperhatikan guru melainkan dia bermain bersama temannya sehingga siswa menjadi kurang fokus dan kurang memperhatikan apa yang di jelaskan oleh guru.

Berdasarkan pada permasalahan yang ada untuk meningkatkan hasil belajar muatan PPKn kelas 4 SDN Ngipik maka untuk itu diperlukan upaya untuk perbaikan dalam kegiatan proses pembelajaran. Siswa harus lebih berperan aktif dalam proses pembelajaran, harus mau berinteraksi dengan guru. Hal tersebut selain bisa untuk dapat meningkatkan hasil belajar muatan PPkn siswa juga dapat memahami setiap materi dengan menemukan pengetahuannya

sendiri. Untuk permasalahan kurangnya kekatifan siswa pada saat proses pembelajaran dan rendah hasil belajar siswa muatan PPKn siswa kelas 4 SDN Ngipik, upaya memperbaiki permasalahan tersebut dengan menerapkan model pembelajaran PBL dalam muatan PPKn.

Dari permasalahan yang ditemukan upaya untuk memperbaiki proses dan hasil belajar muatan PPkn perlu dilakukan. Cara memperbaikinya proses dan hasil belajar muatan PPKn dengan menerapkan salah satu model pembelajaran yaitu model pembelajaran Problem Based Learning (PBL). Pembelajaran PBL adalah pembelajaran yang hanya dapat terjadi jika guru mampu menciptakan lingkungan kelas yang terbuka dan guru dapat membimbing pertukaran pernyataan dari siswa. peran guru disini adalah sebagai pemberi rangsangan kepada siswa dan penentu arah dalam melakukan pengorganisasian kegiatan pembelajaran untuk mencapai tujuan pembelajaran menurut Susilo (2012). Sastrawati dkk 2011 Model pembelajaran PBL adalah pembelajaran yang membuat perubahan dalam proses pembelajarannya khususnya dalam segi peranan guru, dalam hal ini guru tidak hanya menyelesaikan masalah dengan memberikan langkah - langkah penyelesaian yang sudah ditetapkan. Guru dituntut untuk dapat memfasilitasi diskusi pada siswa, memberikan pertanyaan pada siswa atau bisa dilakukan tanya jawab dengan siswa, dan dapat membantu siswa untuk menjadi lebih sadar akan pentingnya suatu pembelajaran. Dari pendapat diatas ada pendapat lain yaitu menurut Prayogi (2013) model pembelajaran ini memiliki langkah - langkah yang mendorong siswa untuk bersikap aktif dalm belajar dengan cara memberikan kesempatan bagi siswa untuk lebih banyak memahami materi pembelajaran, menenukan hal - hal yang diperlukan baik menyangkut materi, meneliti, mengintrogasi, memeroksa materi, sehingga siswa dapat memahami dan berfikir secara matang. Lain halnya menurut Leonda (2015) model pembelajaran PBL mampu merangsang siswa untuk dapat bertanggung jawab terhadap tugasnya. Menuntut persiapan yang matang, menuntut kemampuan yang matang dalam kegiatan intelektual, menuntut semangat tinggi agar dapat mengikuti pembelajaran yang dapat diharapkan, menuntut siswa untuk dapat berfikir kritis dan kreatif jadi siswa lebih giat mengikuti pembelajaran. Model Problem Based Learning merupakan model pembelajaran yang melibatkan siswa dalam memecahkan masalah nyata. Model ini menyebabkan motivasi dan rasa ingin tahu menjadi meningkat (Gunantara, 2014) . Dalam hal ini siswa akan berperan aktif dan dapat meningkatkan hasil belajar siswa. Adapun langkah - langkah 
model pembelajaran PBL Menurut Arends (2008:55) adalah sebagai berikut : 1) mengorientasi siswa pada masalah, 2) mengorganisasi siswa untuk meneliti, 3) membantu investigasu mandiri dan berkelompok, 4) mengembangkan dan menyajikan hasil karya, 5) menganalisis dan mengevaluasi proses pemecahan masalah.

Ada beberapa pengertian hasil belajar menurut Slameto (2003:2) hasil belajar adalah sesuatu proses yang dilakukan oleh seseorang untuk mendapatkan suatu perubahan tingkah laku yang baru secara keseluruhan, sebagai hasil pengelaman sendiri dalam interaksi dengan lingkungan. Susanto (2013:5) menyatakan bahwa hasil belajar adalah perubahan pada siswa dalam aspek kognitif, afektif, dan psikomotoriknya sebagai hasil dan proses belajar. Beliau juga menjelaskan secara sederhana bahwa hasil belajar adalah kemampuan yang didapat oleh siswa setelah mengikuti pembelajaran. Dari pengertian di atas berbeda pengertian menurut Marlina (2010) hasil belajar adalah salah satu kemampuan yang dimiliki oleh siswa setelah siswa menerima pengalaman belajarnya, dan hasil belajar ini sangat penting perannya dalam proses pembelajaran. Hasil belajar suatu perubahan kemampuan yang meliputi kemampuan kognitif, efektif, dan psikomotor. Proses penialian hasil belajar ini dapat memberikan informasi kepada guru tentang kemajuan siswa yang sudah dicapai selama pembelajaran berlangsung. Jadi kesimpulan dari hasil belajar adalah salah satu proses yang dilakukan seseorang untuk merubah perilaku melalui pengalaman dengan lingkungannya yang meliputi afektif, kognitif, dan psikomotor siswa.

Hasil penelitian yang relevan terkait dengan penelitian ini yaitu penelitian dari Wijayanti (2016), menyatakan bahwa penerapan model PBL dapat meningkatkan hasil belajar PPKn. Pada prasiklus ketuntasan mata pelajaran PPKn sebesar 43,75\% berjumlah 8 dan 56,25 siswa belum tuntas atau sama saja dengan 9 siswa. Pada hasil penelitian siklus I dikethui bahwa siswa yang belum tuntas mencapai KKM yaitu 12 siswa atau sama saja dengan $68,75 \%$ dan untuk siswa yang belum tuntas terdapat 5 siswa atau sama dengan $31,25 \%$, dengan memiliki nilai rata - rata 75,31. Dari hasil penelitian menunjukkan meningkatnya persentase belajar pada siklus II, yaitu sebnayak 17 siswa atau semua anak kelas 4 sudah tuntas atau mencapai KKM. Presentase ketuntasan siswa mencapai $100 \%$ dengan memperoleh nilai rata rata kelas pada siklus II sebesar 94,37.

Hasil penelitian relevan yang kedua yaitu hasil penelitian yang telah dilakukan oleh Putu Dian Wahyuni, Luh Putu Putrini Mahadewi, Dewa Nyoman Sudana (2016) dalam jurnal yang berjudul "Penerapan Model Problem Based Learning (PBL) Berbantuan Media Komik Untuk Meningkatkan Hasil Belajar PKn" Penerapan model pembelajaran Problem Based Learning (PBL) berbantuan media komik dapat meningkatkan hasil belajar PKn siswa kelas IVA semester genap tahun pelajaran 2015/2016 di SD Katolik Karya Singaraja. Hal ini ditunjukkan oleh hasil penelitian bahwa hasil belajar PKn siswa mengalami peningkatan dari presentase rata-rata hasil belajar $69,77 \%$ pada siklus I menjadi presentase rata-rata hasil belajar $84,32 \%$ pada siklus II. Dengan demikian terjadi peningkatan sebesar $14,55 \%$ dari siklus I ke siklus II.

Berdasarkan uraian di atas dan pertimbangan untuk meningkatkan hasil belajar muatan PPKn siswa tersebut, peneliti tertarik untuk menerapkan model PBL dalam proses pembelajaran yang akan dilakukan dengan memiliki tujuan dari peneliti sebagai berikut; 1) Menerapkan model Problem Based Learning (PBL) dalam meningkatkan proses tema 8 subtema 1 muatan PPKn siswa kelas 4 SD Negeri Ngipik Kecamatan Pringsurat Kabupaten Temanggung Semester 2 tahun 2017/2018. 2) Melalui peningkatan proses menggunakan model Problem Based Learning (PBL) untuk meningkatkan hasil belajar siswa tema 8 subtema 1 muatan PPKn SD Negeri Ngipik Kecamatan pringsurat Kabupaten Temanggung Semester 2 tahun 2017/2018.

\section{METODE PENELITIAN}

Penelitian ini menggunakan subjek siswa kelas 4 SD Negeri Ngipik yang berjumlah 34 siswa. Terdiri atas 15 perempuan dan 19 laki-laki dengan memiliki latar belakang yang berbeda-beda. Siswa berasal dari lingkungan sekitar sekolah. Sedangkan untuk objeknya penelitian ini menggunakan penelitian tindakan kelas dengan menggunakan model pembelajaran PBL. Peneltian ini berupa suatu tindakan untuk mengatasi masalah yang terkait dengan kegiatan belajar mengajar disuatu kelas.

Dalam kegiatan pembelajaran penelitian tindakan ini menggunakan model spiral menurut Kemmis dan Taggart (Zainal Aqib, 2006:22) yang meliputi "tahap perencanaan, pelaksanaan, tindakan dan observasi, refleksi. Prosedur penelitian dilakukan dalam dua siklus yaitu siklus I dan siklus II dan direncanakan dengan menggunakan langkah-langkah : perencanaan, tindakan dan observasi, serta refleksi. Setiap satu siklus dilaksanakan dalam tiga kali pertemuan. Dua kali untuk proses pembelajaran dan satu kali untuk tes evaluasi. Berikut merupakan prosedur pelaksanaan menurut Kemmis dan Taggar: 


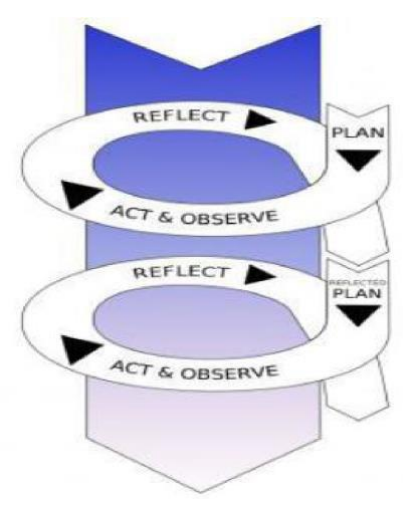

Gambar 1. Prosedur penelitian menurut Kammis dan Taggar

Kegiatan pembelajaran di atas dalam tahap observasi menggunakan lembar observasi guru dan lembar observasi siswa yang telah dibuat sesuai dengan sintak model pembelajaran PBL. Untuk data hasil belajar muatan PPKn menggunakan tes objektif berbentuk pilihan ganda. Penggunaan tes pilihan ganda bertujuan untuk mencakup semua indikator dalam kompetensi dasar. Dari hasil tes tersebut sudah ditemukan beberapa soal yang valid. Hasil uji validitas pada siklus I dari 35 soal pilihan ganda ada 22 soal yang valid, pada siklus II pada 35 soal pilihan ganda ada 24 soal yang valid. Uji reliabilitas pada siklus I memperoleh nilai Cronbach's Alpha sebesar 0,876 dan pada siklus II diperoleh diperoleh nilai Cronbach's Alpha sebesar 0,868.

\section{ANALISIS DAN PEMBAHASAN}

Penelitian tindakan kelas ini dilaksanakan mulai tanggal 30 April sampai dengan 10 Mei 2018. Penelitian ini dilaksanakan melalui 2 siklus dalam setiap siklusnya dan dilakasanakan selama 3 kali tatap muka. Dari hasil pengamatan proses pembelajaran yang dilakukan saat pelaksanaan tindakan., data tentang proses pembelajaran siswa dapat diperoleh melalui penilaian dengan menggunakan lembar observasi guru dan lembar observasi siswa. Isi dari lembar observasi berikut adalah : pendahuluan, mengorientasi siswa pada masalah, mengorganisasi siswa untuk meneliti, membantu investigasu mandiri dan berkelompok, mengembangkan dan menyajikan hasil karya, menganalisis dan mengevaluasi proses pemecahan masalah dan yang terakhir adalah penutup.

Dibawah ini adalah hasil penelitian mengenai proses pembelajatan guru dan siswa dapat dilihat dari tabel berikut:

Tabel 1.Rekapitulasi Pelaksanaan Tindakan Guru dan Siswa

\begin{tabular}{|c|c|c|c|c|c|c|}
\hline \multirow[t]{2}{*}{ No } & \multirow[t]{2}{*}{ Tindakan } & \multirow{2}{*}{$\begin{array}{l}\text { Kondisi } \\
\text { Awal }\end{array}$} & \multicolumn{3}{|c|}{ Siklus I } & \multirow{2}{*}{$\begin{array}{l}\text { Siklus II } \\
\text { Pertemuan II }\end{array}$} \\
\hline & & & Pertemuan I & Pertemuan II & Pertemuan I & \\
\hline 1 & Guru & $67,85 \%$ & $75,73 \%$ & $78,59 \%$ & $90,47 \%$ & $100 \%$ \\
\hline 2 & Siswa & $75 \%$ & $78,51 \%$ & $82,86 \%$ & $90,48 \%$ & $100 \%$ \\
\hline
\end{tabular}

Dari tabel di atas pada kondisi awal tindakan guru memperoleh persentase sebesar 67,85\% yang dicari melalui observasi kondisi awal. Kemudian untuk presentase siswa sebesar 75\% yang dicari melalui observasi siswa. Dan dalam siklus I pertemuan I tindakan guru dalam proses pembelajaran PBL mencapai 75,73\% dan untuk pertemuan ke II 78,59\%, sedangkan untuk tindakan siswa pada siklus I pertemuan I mencapai 78,51\% dan pertemuan II 82,86\%. Pada siklus I belum berjalan dengan baik dan siswa belum antusias untuk melakukan pembelajaran. Siswa belum memahami langkah-langkah yang dijalankan, kurang memahami permasalahan yang diberikan oleh guru. Kurang antusias dalam mengikuti pembelajaran. Pada siklus II pertemuan I tindakan guru dalam proses pembelajaran meningkat menjadi $90,47 \%$ dan untuk pertemuan yang kedua juga mengalami peningkatan yaitu 100\%. Dan untuk siswa 
pada siklus II pertemuan I juga mengalami peningkatan yaitu 90,48\% dan pada siklus II pertemuan II juga mengalami kenaikan yaitu menjadi $100 \%$.

Dari pengumpulan hasil belajar muatan PPKn yang diperoleh siswa melalui pemberian tes yang berbentuk tes pilihan ganda dengan sebanyak 35 soal. Pemberian tes hasil belajar muatan PPKn dilaksanakan pada pertemuan ketiga di setiap siklusnya. Hasil penelitian mengenai hasil belajar muatan PPKn dapat dilihat pada tabel berikut ini:

Tabel 2. Rekapitulasi Hasil Belajar Muatan PPKn

\begin{tabular}{|c|c|c|c|c|c|c|c|}
\hline \multirow[t]{2}{*}{ No } & \multirow[t]{2}{*}{ Ketuntasan } & \multirow[b]{2}{*}{$\mathbf{F}$} & $\begin{array}{l}\text { Kondisi } \\
\text { awal }\end{array}$ & \multicolumn{2}{|c|}{ Siklus I } & \multicolumn{2}{|c|}{ Siklus II } \\
\hline & & & $\%$ & F & $\%$ & $\mathbf{F}$ & $\%$ \\
\hline 1 & Tuntas & 8 & $23,53 \%$ & 2 & $\begin{array}{r}58,82 \\
\%\end{array}$ & 3 & 10 \\
\hline 2 & Tidak Tuntas & 26 & $76,47 \%$ & 1 & $\begin{array}{r}41,18 \\
\%\end{array}$ & 0 & 0 \\
\hline 3 & $\begin{array}{l}\text { Rata - Rata } \\
\text { hasil belajar } \\
\text { muatan PPKn }\end{array}$ & & 60 & & & & \\
\hline & Jumlah & & 10 & 3 & 100 & 3 & 10 \\
\hline
\end{tabular}

Dari tabel di atas dapat diketahui bahwa nilai rata - rata hasil belajar muatan PPKn siswa pada kelas 4 pada saat kondisi awal sebelum diberlakukannya menggunakan model pembelajaran yaitu 60, saat memasuki siklus I nilai rata - rata yang diperoleh siswa yaitu 85, dan nilai rata - rata pada siklus II menjadi 88. Jumlah siswa yang tuntas pada kondisi awal sebanyak 8 siswa dari 34 siswa. saat memasuki siklus I siswa yang tuntas menjadi 20 dari 34 siswa lainnya, dan pada siklus II meningkat menjadi 34 siswa.

Permasalahan pada kondisi awal kurang maksimalnya hasil belajar ini dikarenakan siswa kurang aktif di dalam kelas, siswa juga kurang memahami setiap kata-kata yang ada dalam buku, menjadikan siswa sulit untuk memahami pembelajaran yang diberikan. Hal ini dapat dilihat melalui hasil belajar siswa mengalami penurunan. Sehingga siswa kelas 4 terlihat kurang antusias dalam berinteraksi dengan guru, misalnya saja siswa takut bertanya dengan guru atau menjawab pertanyaan yang diberikan oleh guru dikarenakan siswa belum begitu memahami materi yang diberikan oleh guru dan ketika siswa akan menjawab pertanyaan dari guru atau bertanya sesuatu pertanyaan siswa takut salah menjawab dan salah bertanya. Disisi lain ketika guru menjelaskan di depan kelas siswa biasanya tidak langsung memperhatikan guru melainkan dia bermain bersama temannya sehingga siswa menjadi kurang fokus dan kurang memperhatikan apa yang di jelaskan oleh guru.

Penelitian ini diawali dengan adanya sebuah perencanaan. Pada tahap ini peneliti melakukan mempersiapkan materi dan sumber belajar yang akan digunakan. Selanjutnya, merancang Rencana Pelaksanaan Pembelajaran (RPP) yang berpusat pada sintaks model pembelajaran PBL. Membuat dan menyiapkan lembar kerja siswa. Menyiapkan dan membuat soal evaluasi pada setiap siklusnya. Menyusun dan menyiapkan lembar observasi guru dan siswa sebagai pedoman untuk pengamatan sikap guru maupun siswa.

Yang kedua yaitu tahap pelaksanaan tindakan. Pada tahap ini sudah disesuaikan dengan proses pembelajaran yang meliputi pendahuluan, kegiatan inti, dan kegiatan penutup. Kegiatan pembukaan dilaksanakan dengan do'a bersama dan dilanjutkan dengan melakukan absensi juga menanyakan kabar siswa. Menyanyikan lagu Indonesia Raya dan menyanyikan yel - yel. Lalu melakukan apersepsi dan menyampaikan tujuan pembelajaran yang akan dilaksanakan. Kegiatan inti dilaksanakan sesuai dengan langkah - langkah model PBL yaitu 1) mengorientasi siswa pada masalah, 2) mengorganisasi siswa untuk meneliti, 3) membantu investigasu mandiri dan berkelompok, 4) mengembangkan dan menyajikan hasil karya, 5) menganalisis dan mengevaluasi proses pemecahan masalah. Tahap yang terakhir adalah penutup, pada tahap ini guru melakukan refleksi, menyampaikan materi selanjutnya dan yang terahir berdo'a bersama.

Hasil belajar muatan PPKn siswa yang ditingkatkan dengan menerapkan model pembelajaran PBL dilakukan dalam 2 siklus setiap siklus terdiri dari 3 pertemuan dan setiap pertemuan dilaksanakan dengan alokasi waktu 70 menit. Proses pembelajaran pada siklus I pertemuan pertama tindakan guru memperoleh hasil $75,73 \%$ dan tindakan siswa sebesar 78,51\%. Pada pertemuan pertama ini pembelajaran belum berjalan dengan lancar dikarenakan siswa belum melaksanakan proses 
pembelajaran dengan sesuai yang di harapkan kurangnya natusias siswa mengikuti pembelajaran pada pertemuan pertama, hal ini bisa dilihat dari kegiatan siswa yang kurang memperhatikan dan memahami permasalahan yang diberikan oleh guru. Saat kelompok lain maju kedapan untuk mempresentasikan hasil diskusinya siswa lain masih sibuk dengan bermain dan tidak memperhatikan atau memberi tanggapan kepada temannya yang sedang mempresentasikan hasil diskusinya.

Diperoleh hasil tindakan pada siklus I menunjukan ada peningkatan hasil belajar muatan PPKn dengan perbandingan nilai yang tuntas sebanyak 8 siswa atau 23,53\% sedangkan jumlah siswa yang mendapatkan nilai tidak tuntas sebanyak 26 siswa atau 76,47\% dengan perolehan rata - rata adalah 85 kemudian perolehan nilai tertinggi adalah 89 dan perolehan nilai terendah adalah 50.

Untuk perolehan nilai pada siklus I sudah menunjukkan peningkatan hasil belajar muatan PPKn namun indikator hasil belum menunjukkan keberhasilan secara maksimal karena masih ada siswa yang mendapat nilai di bawah KKM. Pada siklus I masih terdapat kelemahan diantaranya : 1) siswa kurang antusias dalam mengikuti pembelajaran, 2) tidak semua siswa memperhatikan dan memahami permasalahan yang diberikan oleh guru, 3) siswa juga belum menyimpulkan mengenai permasalahan yang telah diselesaikan.

Pada kekurangan siklus I digunakan sebagai acuan untuk melaksanakan siklus selanjutnya, yaitu kegiatan siklus II yang dilaksanakan sebagai tindak lanjut dan penyempurnaan dari siklus I yang dilaksanakan sama seperti kegiatan sebelumnya dengan 3 kali pertemuan dan setiap pertemuan alokasi waktu 70 menit. Hasil kegiatan siklus II yang dilaksanakan sebagai kegiatan tindak lanjut dan penyempurnaan dari siklus I diperoleh hasil belajar yang mengalami peningkatan dibandingkan dengan kegiatan siklus I.

Pada siklus I pertemuan pertama proses tindakan guru pada pembelajaran sebesar $75,73 \%$ dan untuk tindakan aktivitas siswa sebesar 78,51\%. Pada pertemuan pertama ini sudah ada peningkatan namun belum maksimal dengan apa yang di harapkan. Hal ini dapat dilihat ketika kegiatan siswa untuk menyimpulkan tentang masalah yang diberikan oleh guru. Pada siklus I pertemuan kedua proses tindakan guru pada pembelajaran sebesar $78,59 \%$ dan tindakan siswa sebesar $82,86 \%$. Pada pertemuan kedua ini guru dan siswa belum melakukan tindakan sesuai dengan apa yang diharapkan, guru belum melaksanakan sesuai dengan langkah - langkah sintak model pembelajaran PBL. Sedangkan siswa belum berjalan dengan lancar masi ada beberapa siswa yang kurang antusias dan aktif dalam mengikuti proses pembelajaran.

Pada siklus II pertemuan kedua proses tindakan guru pada pembelajaran sebesar $100 \%$. Sehingga dalam pertemuan ini semua sudah berjalan dengan baik sesuai yang diharapkan. Proses tindakan siswa juga sebesar $100 \%$. Sehingga dalam pertemuan ini sisiwa sudah melaksanakan pembelajaran sesuai dengan yang diharapkan. Siswa juga antusias dan aktif dalam mengikuti pembelajaran.

Peningkatan hasil belajar siswa dapat diketahui dengan perolehan nilai siswa kelas 4 mendapatkan ketuntasan 100\% karena dari hasil nilai 34 siswa kelas 4 SDN Ngipik pada siklus II sudah mencapai KKM (70) yang ditetapkan dan perolehan nilai rata - rata siswa adalah 88 dengan perolehan nilai tertinggi adalah 98 dan perolehan nilai terendah adalah 70 .

Dalam hal ini peningkatan proses belajar mengajar ini terjadi karena dalam proses pembelajaran yang menerapkan model PBL. Dengan menggunakan langkah - langkah dalam model pembelajaran PBL menekankan pada kemampuan siswa untuk mengembangkan kemampuan mandiri maupun kelompok. Siswa juga akan aktif dalam proses pembelajaran. Pada model ini siswa akan bertukar pikiran dan menemukan sendiri pengetahuannya sehingga siswa tidak malu dalam bertanya maupun menjawab pertanyaan guru. Hasil penelitian ini sejalan dengan penelitian yang dilakukan oleh Mustamilah (2015) yang menunjukkan bahwa model pembelajaran PBL dapat meningkatkan keterampilan proses dan meningkatkan hasil belajar pada pembelajaran tematik siswa SD kelas 1 SDN 1 Gosono, kecamatan Wonosegoro, Kabupaten Boyolali. Hasil penelitian Wahyuni (2015) menunjukkan bahwa penerapan model pembelajaran Problem Based Larning (PBL) berbantuan media komik dapat meningkatkan hasil belajar PKn siswa kelas IVA SD Katolik Karya Singaraja.

\section{KESIMPULAN}

Berdasarkan hasil temuan dan pembahasan dalam penelitian ini, maka dapat disimpulkan sebagai berikut : 1) Bahwa keaktifan siswa dapat di tingkatkan melalui Penerapan model Problem Based Learning dengan langkah - langkah a) mengorientasi siswa pada masalah, b) mengorganisasi siswa untuk meneliti, c) membantu investigasu mandiri dan berkelompok, d) mengembangkan dan menyajikan hasil karya, e) menganalisis dan mengevaluasi proses pemecahan masalah dapat menigkatkan proses dan hasil belajar muatan PPKn tema 8 subtema 1 kelas 4 SD Negeri Ngipik Kecamatan Pringsurat Kabupaten Temanggung Semester II Tahun 2017/2018. 2) Penerapan model Problem Based Learning dapat meningkatkan proses 
dan hasil belajar muatan PPKn tema 8 sub tema 1 Kelas 4 SD Negeri Ngipik Kecamatan Pringsurat Kabupaten Temanggung Semester II Tahun 2017/2018. Hal ini terlihat dari adanya peningkatan hasil belajar muatan PPKn siswa setiap siklusnya. Pada siklus I persentase hasil belajar muatan IPA adalah $58,82 \%$, sedangkan pada siklus II adalah $100 \%$.

Saran yang dapat disampaikan dalam penelitian ini adalah bagi siswa hendaknya aktif dalam kegiatan, mau berinteraksi dengan guru, tidak malu-malu untuk bertanya ke guru tentang sesuaru yang belum dipahami. Dan untuk guru hendaknya menggunakan strategi yang sesuai dengan kebutuhannya, guna untuk menyempurnakan proses pembelajaran agar dapat meningkatkan hasil belajar muatan PPKn siswa.

\section{DAFTAR PUSTAKA}

Dewi, Luh Putu Puspita Ansari, I.G.A.A.Sri Asri, I Gusti Agung Oka Negara. 2016. Penerapan Model Problem Based Learning Dapat Meningkatkan Keaktifan Dan Kompetensi Pengetahuan Pkn Siswa Kelas V. e-Journal PGSD Universitas Pendidikan Ganesha Jurusan PGSD Vol: 4 No: 1.

Gunantara, Gd. ,Md Suarjana, Pt. Nanci Riastini. 2014. Penerapan Model Pembelajaran Problem Based Learning Untuk Meningkatkan Kemampuan Pemecahan Masalah Matematika Siswa Kelas V. Jurnal Mimbar PGSD Universitas Pendidikan Ganesha Jurusan PGSD Vol: 2 No: 1

Leonda, M. A., Desnita, \& Budi, A. S. (2015). Pengembangan Modul Berbasis Problem Based Learning Untuk Materi Usaha Dan Energi Di SMA (Sesuai Kurikulum 2013). In Prosiding Seminar Nasional Fisika.

Marlina. (2010). Meningkatkan Hasil Belajar Siswa Pada Mata Pelajaran Pkn Melalui Media Pemberian Tugas Di Kelas III SDN 22 Palu. Skripsi Tidak Dipublikasikan .

Maroa, P. P., Kapile, C., \& Hamid, A. (t.thn.). Penerapan Pembelajaran PKn Dengan Media Visual Untuk Meningkatkan Hasil Belajar Pada Siswa Kelas V SD Inpres 012 Bajawali Kecamatan Lariang Kabupaten Mamuju Utara. Jurnal Kreatif Tadulako Online.

Mustamilah . 2015. Peningkatan Keterampilan Proses Dan Hasil Belajar Menggunakan Model Problem Based Learning Pada Sub Tema Merawat Tubuhku Siswa Kelas 1 Sd Negeri 1 Gosono Wonosegoro. Scholaria, Vol. 5, No. 2, Mei 2015: 70 - 79.

Prayogi , S., \& Asy'ari, M. (2013). Model PBL (Problem Based Learning) Untuk Meningkatkan Hasil Belajar Dan Kemampuan Berpikir Kritis Siswa. Jurnal Prisma Sains 1(1).

Rahmasari, R. (2016). Penerapan Model Pembelajaran Problem Based Leraning Untuk Meningkatkan Hasil Belajar Ipa Kelas IV SD. Jurnal Pendidikan Guru Sekolah Dasar.

Sastrawati, E., Rusdi, M., \& Syamsurizal. (2011). Problem Based Learning Strategi Metakognisi Dan ketrampilan Berfikir Tingkat Tinggi Siswa . Jurnal Tekno-Pedagogi, 1-14.

Slameto. (2003). Belajar dan Faktor-faktor yang Mempengaruhinya. Jakarta: PT Rineka Cipta.

Sumenari, K. (2018). Meningkatkan Prestasi Belajar Ipa Melalui Penerapan Model Pembelajaran Problem Based Learning . Journal of Education Action Research.

Susanto, A. (2013). Teori Belajar Dan Pembelajaran Di Sekolah Dasar. Jakarta: Kencana Predana Media Group.

Susilo, A. B., Wiyanti, \& Supartono. (2012). Model Pembelajaran Ipa Berbasis Masalah Untuk Meningkatkan Motivasi Belajar DanBerfikir Kriris Siswa SMP. Unnes Science Education Journal.

Wahyuni, P. D., Mahadewi, L. P., \& Sudana, D. N. (2016). Penerapan Model Problem Based Learning (PBL) Berbantuan Media Komik Untuk Meningkatkan Hasil Belajar PKn. Jurnal Pendidikan Guru Sekolah Dasar.

Widyasari, Putu Ayuna, Made Putra, I Ketut Adnyana Putra. 2016. Penerapan Model Problem Based Learning untuk Meningkatkan Aktivitas Belajar dan Penguasaan Kompetensi Pengetahuan PKn Siswa IVB SDN 22 Dauh Puri. e-Journal PGSD Universitas Pendidikan Ganesha Jurusan PGSD Vol: 4 No: 1. 
Widyaningrum, Diyah Ayu. 2016. Penerapan Model Problem Based Learning (Pbl) Dipadu Student Team Achievement Division (STAD) Melalui Lesson Study (LS) Untuk Meningkatkan Aktivitas dan Hasil Belajar Siswa Man 3 Malang. JURNAL PEDAGOGIA ISSN 2089 -3833 Volume. 5, No. 1.

Wijayanti, R. (2016). Peningkatan Prestasi Belajar PKn Melalui Penerapan Model Pembelajaran Problem Based Learning. Jurnal Pendiidkan Guru Sekolah Dasar 